\title{
Therapeutic vaccines in HBV: lessons from HCV
}

\author{
Eleanor Barnes
}

Received: 23 July 2014 / Accepted: 7 October 2014 / Published online: 9 January 2015

(C) The Author(s) 2014. This article is published with open access at Springerlink.com

\begin{abstract}
Currently, millions of people infected with hepatitis B virus (HBV) are committed to decades of treatment with anti-viral therapy to control viral replication. However, new tools for immunotherapy that include both viral vectors and molecular checkpoint inhibitors are now available. This has led to a resurgence of interest in new strategies to develop immunotherapeutic strategies with the aim of inducing HBeAg seroconversion-an end-point that has been associated with a decrease in the rates of disease progression. Ultimately, a true cure will involve the elimination of covalently closed circular DNA which presents a greater challenge for immunotherapy. In this manuscript, I describe the development of immunotherapeutic strategies for HBV that are approaching or currently in clinical studies, and draw on observations of $\mathrm{T}$ cell function in natural infection supported by recent animal studies that may lead to additional rational vaccine strategies using checkpoint inhibitors. I also draw on our recent experience in developing potent vaccines for HCV prophylaxis based on simian adenoviral and MVA vectors used in prime-boost strategies in both healthy volunteers and HCV infected patients. I have shown that the induction of $\mathrm{T}$ cell immune responses is markedly attenuated when administered to people with
\end{abstract}

This article is part of the speical issue "Therapeutic vaccination in chronic hepatitis B-approaches, problems, and new perspectives".

\section{E. Barnes}

The Jenner Institute, The Oxford NIHR BRC and the Oxford Martin School, Oxford, UK

\section{E. Barnes $(\bowtie)$}

The Peter Medawar Building for Pathogen Research, Oxford University, South Parks Rd, Oxford OX1 3SY, UK

e-mail: ellie.barnes@ndm.ox.ac.uk persistent HCV viremia. These studies and recently published animal studies using the woodchuck model suggest that potent vaccines based on DNA or adenoviral vectored vaccination represent a rational way forward. However, combining these with drugs to suppress viral replication, alongside checkpoint inhibitors may be required to induce long-term immune control.

Keywords $\mathrm{HBV} \cdot$ Immunotherapy · Adenoviral vectors · $\mathrm{HCV} \cdot$ Checkpoint inhibitors

\section{The goals for HBV immunotherapy}

There has been a recent resurgence in interest to develop novel strategies for therapeutic vaccination against hepatitis $\mathrm{B}$ virus (HBV) within both academia and pharma. This has primarily been driven by progress in the treatment of HBV and changing therapeutic goals and new tools for immunotherapy that include both viral vector strategies and molecular checkpoint inhibitors. A number of new drugsprincipally tenofovir and entecavir - that are safe and well tolerated with a high barrier to resistance have recently revolutionised the treatment of HBV [1-4]. However, with time it has been clear that the rates of HBV surface antigen (HBsAg) loss and HBV "e" antigen (HBeAg) seroconversion with these new therapies are very low so committing most patients to lifelong therapy $[4,5]$. Furthermore, deploying lifelong therapies in resource-poor countries where the rates of HBV infection are the highest is rarely an option. In addition, there are emerging efforts to provide cure for HIV infection where some of the challenges parallel those found in HBV including persisting viral genomes and lifelong therapies [6]. Together, these observations have provided a new impetus to identify new strategies to 
cure HBV infection in patients currently receiving antiviral therapy.

Hope that immunotherapy may be a successful strategy for HBV comes from two observations; firstly, that robust adaptive immune responses are associated with viral control during acute HBV infection disease [7-9] and secondly, that in chronic HBV disease, spontaneous viral control with suppression of HBV DNA is associated with immune activation as evidenced by $\mathrm{HBeAg}$ seroconversion and liver inflammation with a flare in liver alanine transaminases (ALT) [10]. This is in contrast to human immunodeficiency virus (HIV) where persistent infection is almost always established after primary disease and to hepatitis $\mathrm{C}$ virus (HCV) infection, where immune control associated with spontaneous viral control is established is exceedingly rare once chronic disease is established.

The goals of immunotherapy are therefore twofold: (1) To induce $\mathrm{HBeAg}$ seroconversion in those on therapy; this end-point has been associated with lower rates of disease progression to cirrhosis and hepatocellular carcinoma, an increase in the rates of HBsAg seroconversion, and improved survival rates [11], and (2) more ambitiously, to provide a complete cure that would require the elimination of HBV covalently closed circular (ccc) DNA and therefore disappearance of its major expression product HBsAg with or without anti-HBs seroconversion.

A number of strategies are available for HBV immunotherapy. Some of these rely on emerging molecular technologies and include $\mathrm{T}$ cell receptor gene transfer and therapeutic antibody conjugates. However, these are technically challenging, carry significant safety concerns and are unlikely to be applicable in resource-poor settings. These technologies are discussed in detail by Bertoletti et al. in this issue. This article will therefore focus on new technologies that are close to the clinic, in particular, strategies to enhance adaptive immune responses, specifically $\mathrm{T}$ cells, and how these may be successfully combined with oral therapies and other adjuvants.

\section{The rationale for $\mathrm{HBV}$ immunotherapeutic approaches}

One of the key challenges for immunotherapy is the development of strategies that enhance adaptive $\mathrm{T}$ cell responses in the setting of chronic high-level antigen exposure. A hallmark of persistent infection with HBV is a markedly attenuated or "exhausted" $\mathrm{T}$ cell response; low in magnitude, narrowly focused, poorly proliferative, and producing low levels of interleukin (IL)-2 [12, 13]. Advancing our understanding of the underlying mechanism for $\mathrm{T}$ cell attenuation is important for the development of rational therapeutic strategies. HBV infection is characterised by the persistent production of very high quantities of subviral
HBsAg particles, and a secreted form of HBV core antigen named "e" antigen (HBeAg) that exceeds by a thousandfold or more the amount needed for assembly of complete HBV particles. However, the direct role of exposure to these antigens in attenuating $\mathrm{T}$ cell immunity is controversial. Since HBV polymerase is not secreted in this way and $\mathrm{T}$ cell responses to polymerase are also attenuated, it is unlikely that these antigens are wholly responsible for the exhausted $\mathrm{T}$ cell profile observed.

Certainly, there is mounting evidence that $\mathrm{T}$ cell priming in a tolerating liver environment is likely to be critical, in addition to the premature death of $\mathrm{HBV}$-specific $\mathrm{T}$ cells in the liver through proapoptotic protein Bcl2-interacting mediator (Bim)-dependent mechanisms [14, 15]. Furthermore, HBV has been shown to induce the liver enzyme arginase that depletes hepatic arginine resulting in $\mathrm{T}$ cells that are poorly proliferative [16]. A unifying hypothesis then is that HBV-specific $\mathrm{T}$ cells may be driven to apoptosis through the interplay between (1) high dose antigen, (2) the high expression of inhibitory signals, and (3) lack of co-stimulatory molecules and other inhibitor mechanisms within the liver. Immunotherapeutic strategies should seek then to target these factors and to induce functional antiviral $\mathrm{T}$ cells by vaccination.

\section{HBV viral suppression}

Taking these factors in turn, the suppression of HBV viral replication may be readily achieved using current oral therapies. This would serve two purposes - to reduce the chance of immunopathology in the context of immunotherapeutic vaccination and possibly to facilitate the recovery of adaptive immune responses. Mouse models of lymphocytic choriomeningitis virus (LCMV) infection suggest that recovery of adaptive responses are best achieved in the setting of low viral load [17], and in support of this, there is good evidence that HBV viral load suppression with oral anti-viral therapy is sometimes associated with immune activation and $\mathrm{HBeAg}$ seroconversion [18]. More typically, however, in the absence of HBeAg seroconversion, viral suppression with oral therapies is associated with a transient, early, and minimal increase in adaptive immune responses only [19]. Theoretically, it is plausible that intermittent, low levels of viral replication are required to stimulate immune control of virus. It should be noted that whilst oral anti-virals reduce infectious virus through the inhibition of HBV reverse transcriptase, they have little effect on HBV antigen levels that are generated through transcription by RNA polymerase II, and no direct effect on HBV ccc DNA. Overall, since viral load suppression alone is generally insufficient to restore adaptive response, successful immunotherapy will need to be combined with additional strategies. 
Checkpoint inhibition

The high expression of inhibitory molecules on HBV-specific $\mathrm{T}$ cells is well described and provides some interesting molecular targets for additional immunotherapeutic strategies including programmed cell death protein 1 (PD-1), cytotoxic T lymphocyte antigen 4 (CTLA-4), 2B4, T cell membrane protein 3 (Tim-3), Lymphocyte-activation gene 3 (LAG-3), and their ligands-some of which are currently available for clinical use or in late stage development.

To date, these checkpoint inhibitors have largely been given to patients with advanced malignancy. CTLA-4 has been linked to Bim expression, and the blocking of CTLA-4 in vitro has been linked to the expansion of HBVspecific T cells. HBV viral load suppression with anti-viral therapy is not associated with a reduction in CTLA-4 or Bim levels on human HBV-specific T cells [15]. CTLA-4 inhibitors are currently available in the clinic; ipilimumab (BMS) has been used successfully to treat patients with a range of malignancies including melanoma, prostate, and renal cancer, and was approved in 2011 by US regulators for the treatment of melanoma. However, this monoclonal antibody has been associated with immune-related side effects that include reversible colitis, rashes, and hepatitis [20]. In practice, it is unlikely that CTLA-4 checkpoint inhibitors will move into clinical studies of HBV in the near future since the safety profile of these are unacceptable in HBV patients who are otherwise well.

PD-1 and PD-1 ligand inhibitors are also in advanced development including three monoclonal antibodies, and three other drugs (reviewed in [21]) now in phase-I to phase III clinical trials. Therapeutic anti-PD-1 antibodies have been assessed in three chimpanzees and in humans with chronic HCV infection, but not in human studies of HBV infection. In one study of three chimpanzees chronically infected with $\mathrm{HCV}$, pre-existing intrahepatic $\mathrm{T}$ cell responses and $\mathrm{CD} 4+$ and $\mathrm{CD} 8+\mathrm{HCV}$-specific $\mathrm{T}$ cells were restored, associated with a transient but substantial decline in HCV viral load showing for the first time that reversal of $\mathrm{T}$ cell tolerance induced by hepatotropic viruses is possible [22]. The anti-PD-1 monoclonal immunoglobulin G4 (Nivolumab; BMS-936558) was subsequently assessed in 54 patients with chronic HCV infection; five achieved a $>0.5 \log$ decline in HCV viral load, two achieved a viral load decline below the level of detection, and one patient became HCV undetectable. Immune-related side effects were seen in six patients, and in one patient, there was a grade 4 elevation in ALT associated with viral decline [23]. Overall, grade 3 and grade 4 adverse events have been seen in around $15 \%$ of patients including deaths from pneumonitis in oncology patients treated with nivolumab [24].

In spite of the significant adverse event profile, it is likely that anti-PD-1 immunotherapeutic strategies will be assessed in HBV phase-I studies in the short term. Clinical experience in the use of anti-PD-1 strategies is growing, and overall the side effects are thought to be manageable. Furthermore, recent animal studies using a woodchuck model have shown promise for immunotherapeutic strategies targeting the PD-1 pathway as an adjunct to vaccination; PD-1 blockade in combination with both entecavir and DNA vaccination increased virus-specific $\mathrm{T}$ cell function associated with anti-woodchuck hepatitis surface antibodies and viral eradication in some animals [25]. LAG-3 inhibitors are currently in phase-I clinical studies of solid tumours (ClinicalTrials.gov NCT01968109), whilst TIM-3 inhibitors are in advanced pre-clinical development.

\section{Lessons from studies of HBV immunotherapy}

Previous attempts at therapeutic HBV vaccination have induced very low levels of $T$ cells with minimal effects on viral suppression or HBV seroconversion events. Early efforts utilised HBsAg protein vaccines primarily inducing antibodies with minimal effects in established infection [26-28]. HBV single and multi-epitope string vaccines have induced little immunogenicity, and these approaches are unlikely to give sufficient coverage across HBV genotypes, or between people of distinct HLA types [29].

DNA vaccinations that encode small (S) and middle (preS2 and S) envelope proteins have also had limited success; these have induced anti-preS2 antibodies and $\mathrm{HBeAg}$ seroconversion in the minority of $\mathrm{HBV}$ vaccines $(2 / 10)$ associated with weak and transient $\mathrm{T}$ cell responses [30, 31]. However, repeated vaccinations $(n=12)$ with DNA encoding $\mathrm{S}$, preS1/S2, core, polymerase and $\mathrm{X}$ proteins with genetically adjuvanted IL-12 and oral anti-virals induced a multi-specific $\mathrm{T}$ cell response, sustained viral suppression, and $\mathrm{HBeAg}$ seroconversion in 6/12 patients $[32,33]$. A recent pilot study of 36 patients with chronic HBV infection used electroporated DNA encoding HBV middle $\mathrm{S}$ protein with an IL-12/IFN gamma fusion protein given with lamivudine. This was associated with the generation of $\mathrm{T}$ cell immune responses with a reduction in HBV viral load in some people [33]. However, DNA vaccine strategies that require painful electroporation or multiple injections to generate significant immune responses are unlikely to be widely clinically applicable. For these reasons, heterologous prime/boost vaccination strategies using viral vectors have been assessed as an alternative strategy. DNA prime/MVA boost vaccine encoding S, preS1/ S2 showed promise in a chimpanzee study [34]. However, when the same vaccine was assessed in a clinical study in Gambia given with or without lamivudine, there was no $\mathrm{T}$ cell induction or reduction in viremia [35]. The reasons for this may relate to the fact that the vaccine contained $S$ and preS immunogens only. However, strategies that reduce 
HBV viral load with drug therapy before DNA prime/Ad boost encoding HBV core has shown real promise in the HBV woodchuck model; this strategy was able to induce a robust $\mathrm{CD} 4+$ and $\mathrm{CD} 8+\mathrm{T}$ cell response associated with control of viremia and HBsAg seroconversion [36]. Transgene, a French biopharmaceutical company developing viral vectored approaches for the treatment of infectious disease, is planning to assess non-replicative $\operatorname{Ad} 5$ vectors (TG1050) encoding multiple HBV antigens (Core, Polymerase and Envelope) from genotype D HBV in China in late 2014 (press-release July 2014).

Innate immune stimulation

One of the advantages of a virally vectored vaccine is that the vectors themselves will induce innate immune responses. This may be important given the observation that innate immune stimulation alone may be associated with HBV viral control though mechanisms that are currently not clear. For example, the administration of Granulocyte-macrophage colony-stimulating factor (GM-CSF) has been associated with HBV DNA and/or HBeAg loss in up to $60 \%$ of treated patients [37, 38]. Furthermore, a comparison of two consecutive studies assessing an antigenantibody (HBsAg-HBIG) immunogenic complex therapeutic vaccine candidate with alum as adjuvant and alum alone as placebo suggested that increasing the frequency of dosing with alum alone could increase the rates of $\mathrm{HBeAg}$ seroconversion [39, 40]. Validation of this observation, however, would require a head-to-head comparison of the effects of the frequency of alum dosing within the same study. Additional strategies that aim to block regulatory or induce stimulatory cytokines should also been considered. IL-10 levels are elevated during chronic disease, and in vitro IL-10 blockade can restore HBV-specific T cell functionality [41]. However, in acute disease, elevated plasmaIL-10 levels have been associated with the attenuation of T cell immunity during acute infection [42] and with hepatic inflammatory flares during acute disease suggesting that in this setting, IL-10 potentially regulates immunopathology. Together, these studies highlight the critical role that IL-10 may play in balancing immunopathology with persistent viremia (reviewed in Couper KN 2008 [43]). Although IL-10 blockade facilitates DNA vaccine-induced $\mathrm{T}$ cell responses and enhances clearance of persistent LCMV infection [44], it is unlikely that IL-10 blockade will move into human studies of $\mathrm{HBV}$ as an immunotherapeutic or as an adjuvant in the short/medium term, given the risks of immunopathology. IL-12 is also a candidate as this has recently been shown in vitro to enhance the cytotoxicity, polyfunctionality, and multispecificity of HBVspecific T cells and combining IL-12 with blockade of the PD-1 pathway further increased the functionality of CD8+
HBV-specific $\mathrm{T}$ cells [45]. Recombinant human IL-12 has been used in cancer immunotherapy, and whilst antitumour effects have been limited, IL-12 has been shown to be well tolerated and to induce cellular immunity [46]. Genetic HBV vaccines that encode IL-12 have shown promise as discussed above [32].

\section{Lessons from HCV immunotherapy-viral vectored technologies}

The recent development of viral vectored technology to deliver immunogens has been a major step forward in the field, with the capacity now to generate unprecedented levels of T cells in healthy volunteers. Earlier work from the Merck HIV and Oxford malaria vaccine programs used replicative defective adenoviral vectors to prime $T$ cell responses [47]. However, one of the limitations of this technology is the presence of pre-existing anti-vector immunity that may attenuate vaccine responses. However, the use of chimpanzee adenoviruses, to which humans have no prior exposure, can overcome this issue [48].

Important lessons can be learnt from our recent studies of immunotherapy in HCV infection using chimpanzee adenovirus that may also now be applicable to immunotherapy for HBV. In collaboration with an SME Okairos (Rome, Italy), we have recently shown that vaccination with adenoviral vectors derived from chimpanzee (AdCh3) and rare human adenovirus serotypes (AdHu6) encoding the non-structural (NS) proteins of $\mathrm{HCV}$ induce a very high magnitude of durable $\mathrm{T}$ cell responses, with a broad specificity in healthy volunteers [49]. The key observations that viral load is inversely correlated with CD8+ T cell function in chronic HBV disease [50], the association of classII alleles with viral persistence [51], and that CD4+ and CD8+ blocking experiments are associated with viral persistence in chimpanzees [8] show that both $\mathrm{T}$ cell subsets will need to be induced during immunotherapy.

Our recent data show that heterologous boosting following adenoviral prime with modified vaccinia Ankara (MVA) encoding the same immunogen further enhances both CD8+ and CD4+ T cell subsets in healthy individuals [49]. This strategy shows real promise as a prophylactic vaccine strategy and is now in efficacy testing in Baltimore in a large population of intravenous drug users at a high risk of exposure to $\mathrm{HCV}$ infection (ClinicalTrials.gov NCT01436357).

We have also applied the same vaccine strategy to patients with chronic HCV genotype-1 infection to assess for the first time, the capacity of a potent $\mathrm{T}$ cell vaccine to restore adaptive immunity in chronic $\mathrm{HCV}$ viremia. Vaccination was performed in the setting of a high $\mathrm{HCV}$ viral load, and in the setting of a suppressed viral load 2 
or 14 weeks into interferon and ribavirin therapy. Overall, we were able to show that $\mathrm{T}$ cells were induced to very high levels in a minority of patients, irrespective of viral suppression [52]. However, in those patients, analysis of the host circulating HCV viral sequence showed significant variation in epitopes targeted by vaccine-induced $\mathrm{T}$ cells, in comparison with the vaccine immunogen [53]. Overall, we learnt three important lessons from these studies. Firstly, viral load suppression and vaccination with a demonstrably potent vaccine may not be sufficient to restore adaptive immune responses. Secondly, vaccine-induced $\mathrm{T}$ cell responses cannot be interpreted without a detailed knowledge of the sequence of the endogenous virus in vaccinees, and thirdly, it is not possible to assess the potency of a vaccine applied in patients with chronic infection if this vaccine has not been first assessed in healthy volunteers.

Each of these lessons may now usefully be applied to vaccine studies of immunotherapy in HBV infectionthough there are a number of important differences. In the HCV immunotherapy studies described above, the assessment of the effect of viral load suppression on T cell restoration is confounded by the fact that interferon (IFN) therapy is known to have immunosuppressive and antiproliferative effects [54]. A similar study in HBV could use HBV anti-viral suppression free from these effects. Also the viral diversity of HBV is much reduced compared with $\mathrm{HCV}$, so that the capacity of a vaccine to induce $\mathrm{T}$ cells that do not cross-react with circulating virus is reduced. Nevertheless, HBV viral sequence analysis should be employed for the meaningful interpretation of vaccine-induced $T$ cell responses. And finally, new HBV vaccines should be assessed in healthy people first so that the potency of the vaccine is established. In the generation of a successful HBV immunotherapeutic vaccine, the design of the HBV immunogen will clearly be critical. Since adenoviral vectors can encode large immunogens ( $>1,500$ amino acids) HBV surface, core and polymerase antigens could be encoded in a first generation HBV immunotherapeutic vaccine (see also the article by Kosinska et al. in this issue).

In the HCV studies, we saw no conclusive evidence of immunopathology in vaccinated subjects. This is not surprising given the fact that vaccine-induced $\mathrm{T}$ cells rarely targeted endogenous virus. Furthermore, in HCV, only $4 \%$ of hepatocytes are thought to be infected [55], and severe hepatic inflammation associated with adaptive immunity is rarely observed in natural $\mathrm{HCV}$ infection. The same may not be true in HBV where the majority of hepatocytes are infected in chronic disease and where fulminant liver failure is associated with adaptive immune responses during primary infection, during seroconversion events in chronic disease, and during immune reconstitution after reactivation of occult HBV infection. The co-administration of oral anti-virals reducing HBV load should significantly reduce the risks of serious immunopathology as new vectors are given to patients for the first time. Thus, immunotherapeutic strategies for HBV will need to tread a careful line aiming to induce immune events associated with HBV seroconversion without inducing severe hepatic inflammation.

The repeated administration of attenuated poxvirus as viral vectors has been assessed by Transgene (France). MVA viral vectors encoding HCV NS proteins (TG4040) were administered repeatedly $(n=6)$ in patients with chronic HCV infection associated with a transient decline in HCV RNA levels in some people [56]. In a phase-II study, this regimen was associated with early viral clearance, but not a statistically significant increase in sustained virological response [57]. Whilst this approach was able to induce HCV-specific T cells, these studies did not evaluate the capacity of vaccine-induced $\mathrm{T}$ cells to target endogenous virus in patients.

\section{cccDNA eradication}

The elimination of nuclear cccDNA is required if $\mathrm{HBV}$ is to be cured, and this represents a major challenge for HBV immunotherapy. The issue of HBV cccDNA eradication is not easily addressed since cccDNA infects $40-100 \%$ of hepatocytes and has in most cases a lifespan as long as the hepatocyte. It has long been known that the administration of IFN- $\alpha$ therapy in patients with chronic HBV infection, and particularly those with elevated transaminases at baseline may be associated with cure in a minority of people. HBV cure is defined as HBsAg loss and antiHBs seroconversion which is believed to indicate eradication or inactivation of cccDNA. Furthermore, there is an increased incidence of cure in these patients that continues for some years after the cessation of therapy. It is evident that innate mechanisms are capable of cccDNA eradication. Supporting studies in animal models of HBV, primary hepatocytes, and human liver needle biopsies have demonstrated that interferon- $\alpha$ and lymphotoxin- $\beta$ receptor activation may upregulate nuclear deaminases (APOBEC $3 \mathrm{~A}$ and APOBEC3B) mediated by HBV core resulting in cccDNA degradation that prevents HBV reactivation [58].

Recent studies sponsored by Gilead sciences have developed a selective oral TLR-7 agonist (GS-9620) with the aim of curing chronic HBV infection. A study in three chimpanzees with chronic infection showed that this compound was able to suppress viral load by $>1 \log$ for some months, associated with the stimulation of interferon- $\alpha$ and interferon stimulated genes, chemokines, and natural killer cells. An increase in hepatocyte apoptosis was associated with a fall in serum HBsAg, HBeAg, and HBV antigen positive hepatocytes. [59] Gilead has since moved into human studies. Three clinical trials were started in 2013 people with chronic hepatitis B. Two of the studies have 
been completed and results are pending. The third study is on-going (ClinicalTrial.gov NCT01590654).

Studies on HIV that aim to cure patients are hoping to induce reactivation of latently infected cells using histone deacetylases inhibitors (HDACi) to induce viral transcription in latently infected cells in patients on HAART, in conjunction with immunotherapeutic approaches [60]. Similar strategies may be developed for HBV immunotherapy. However, the replication-competent HBV cccDNA is not integrated in the host genome and may not be activated by HDACi, and whilst the integrated forms of HBV DNA may be silenced, these are not responsible for the generation of infectious virus. The success of any approach that sought to eliminate cccDNA would most likely rely on the coadministration of oral HBV anti-virals or HBV viral entry inhibitors targeting HBV receptors $[61,62]$ to prevent the replenishment of the latently infected viral pool.

\section{Conclusion}

In summary, new therapeutic strategies that aim to induce long-term HBV immune control or provide a complete cure through the elimination of cccDNA will be assessed in phase-I/II clinical studies in the short/medium term. These are likely to proceed cautiously, and in a step-wise fashion in patients without significant liver fibrosis and in patients where viral load is suppressed with oral anti-virals therapy. Highly immunogenic vaccines based on adenoviral and MVA vectors used in prime-boost strategies are now available for clinical studies, and the use of simian adenoviruses overcomes the issue of pre-existing vector immunity. The choice of immunogen will be critical but will to some extent require a "test and see" approach in humans. Nevertheless, it would seem prudent to include polymerase, core, and possibly preS/S antigens in a first generation vaccine. Our own data from immunotherapeutic studies of HCV suggest that potent vaccines alone may not be sufficient to restore the function of $\mathrm{T}$ cells that have been exposed to antigen for many years and additional strategies such as the co-administration of checkpoint inhibitors and adjuvants that aim to induce innate immunity will also be required. New platforms in viral vectored technology and molecular approaches mean that immunotherapy for HBV that seeks to control and/or cure HBV replication is now a real possibility.

Acknowledgments E. B is funded by the Medical Research Council UK, and supported by the Oxford NIHR BRC and the Oxford Martin School.

Conflict of interest E. B is developing therapeutic and prophylactic vaccines strategies for $\mathrm{HCV}$ (in collaboration with Okairos, Italy). The work has been supported through EU and MRC UK external Grant funded programs. E. B has no financial conflicts of interest.
Open Access This article is distributed under the terms of the Creative Commons Attribution License which permits any use, distribution, and reproduction in any medium, provided the original author(s) and the source are credited.

\section{References}

1. Marcellin P, Heathcote EJ, Buti M, Gane E, de Man RA, Krastev Z, Germanidis G, Lee SS, Flisiak R, Kaita K, Manns M, Kotzev I, Tchernev K, Buggisch P, Weilert F, Kurdas OO, Shiffman ML, Trinh H, Washington MK, Sorbel J, Anderson J, Snow-Lampart A, Mondou E, Quinn J, Rousseau F (2008) Tenofovir disoproxil fumarate versus adefovir dipivoxil for chronic hepatitis B. N Engl J Med 359:2442-2455

2. Lai CL, Shouval D, Lok AS, Chang TT, Cheinquer H, Goodman Z, DeHertogh D, Wilber R, Zink RC, Cross A, Colonno R, Fernandes L (2006) Entecavir versus lamivudine for patients with HBeAg-negative chronic hepatitis B. N Engl J Med 354:1011-1020

3. Chang TT, Gish RG, de Man R, Gadano A, Sollano J, Chao YC, Lok AS, Han KH, Goodman Z, Zhu J, Cross A, DeHertogh D, Wilber R, Colonno R, Apelian D (2006) A comparison of entecavir and lamivudine for HBeAg-positive chronic hepatitis B. N Engl J Med 354:1001-1010

4. Chan HL, Chan CK, Hui AJ, Chan S, Poordad F, Chang TT, Mathurin P, Flaherty JF, Lin L, Corsa A, Gaggar A, Subramanian GM, McHutchison JG, Lee S, Gane EJ (2014) Effects of tenofovir disoproxil fumarate in hepatitis B e antigen-positive patients with normal levels of alanine aminotransferase and high levels of hepatitis B virus DNA. Gastroenterology 146:1240-1248

5. Li MR, Xi HL, Wang QH, Hou FQ, Huo N, Zhang XX, Li F, Xu $X Y$ (2014) Kinetics and prediction of HBsAg loss during longterm therapy with nucleos(t)ide analogues of different potency in patients with chronic hepatitis B. PLoS One 9:e98476

6. Frater J (2011) New approaches in HIV eradication research. Curr Opin Infect Dis 24:593-598

7. Rehermann B, Fowler P, Sidney J, Person J, Redeker A, Brown M, Moss B, Sette A, Chisari FV (1995) The cytotoxic $\mathrm{T}$ lymphocyte response to multiple hepatitis B virus polymerase epitopes during and after acute viral hepatitis. J Exp Med 181:1047-1058

8. Thimme R, Wieland S, Steiger C, Ghrayeb J, Reimann KA, Purcell RH, Chisari FV (2003) CD8(+) T cells mediate viral clearance and disease pathogenesis during acute hepatitis B virus infection. J Virol 77:68-76

9. Shimada N, Yamamoto K, Kuroda MJ, Terada R, Hakoda T, Shimomura H, Hata H, Nakayama E, Shiratori Y (2003) HBcAgspecific CD8 $\mathrm{T}$ cells play an important role in virus suppression, and acute flare-up is associated with the expansion of activated memory T cells. J Clin Immunol 23:223-232

10. Liaw YF (2003) Hepatitis flares and hepatitis B e antigen seroconversion: implication in anti-hepatitis B virus therapy. J Gastroenterol Hepatol 18:246-252

11. Liaw YF (2009) HBeAg seroconversion as an important end point in the treatment of chronic hepatitis B. Hepatol Int 3:425-433

12. Lauer GM, Barnes E, Lucas M, Timm J, Ouchi K, Kim AY, Day CL, Robbins GK, Casson DR, Reiser M, Dusheiko G, Allen TM, Chung RT, Walker BD, Klenerman P (2004) High resolution analysis of cellular immune responses in resolved and persistent hepatitis C virus infection. Gastroenterology 127:924-936

13. Klenerman P, Hill A (2005) T cells and viral persistence: lessons from diverse infections. Nat Immunol 6:873-879

14. Knolle PA, Gerken G (2000) Local control of the immune response in the liver. Immunol Rev 174:21-34 
15. Chang JJ, Thompson AJ, Visvanathan K, Kent SJ, Cameron PU, Wightman F, Desmond P, Locarnini SA, Lewin SR (2007) The phenotype of hepatitis $\mathrm{B}$ virus-specific $\mathrm{T}$ cells differ in the liver and blood in chronic hepatitis B virus infection. Hepatology 46:1332-1340

16. Sandalova E, Laccabue D, Boni C, Watanabe T, Tan A, Zong HZ, Ferrari C, Bertoletti A (2012) Increased levels of arginase in patients with acute hepatitis B suppress antiviral T cells. Gastroenterology 143(78-87):e73

17. Wherry EJ, Blattman JN, Ahmed R (2005) Low CD8 T-cell proliferative potential and high viral load limit the effectiveness of therapeutic vaccination. J Virol 79:8960-8968

18. Wong GL, Wong VW, Chan HY, Tse PC, Wong J, Chim AM, Yiu KK, Chu SH, Chan HL (2012) Undetectable HBV DNA at month 12 of entecavir treatment predicts maintained viral suppression and $\mathrm{HBeAg}$-seroconversion in chronic hepatitis $\mathrm{B}$ patients at 3 years. Aliment Pharmacol Ther 35:1326-1335

19. Boni C, Penna A, Bertoletti A, Lamonaca V, Rapti I, Missale G, Pilli M, Urbani S, Cavalli A, Cerioni S, Panebianco R, Jenkins J, Ferrari C (2003) Transient restoration of anti-viral T cell responses induced by lamivudine therapy in chronic hepatitis B. J Hepatol 39:595-605

20. Weber J (2007) Review: anti-CTLA-4 antibody ipilimumab: case studies of clinical response and immune-related adverse events. Oncologist 12:864-872

21. Mullard A (2013) New checkpoint inhibitors ride the immunotherapy tsunami. Nat Rev Drug Discov 12:489-492

22. Fuller MJ, Callendret B, Zhu B, Freeman GJ, Hasselschwert DL, Satterfield W, Sharpe AH, Dustin LB, Rice CM, Grakoui A, Ahmed R, Walker CM (2013) Immunotherapy of chronic hepatitis $\mathrm{C}$ virus infection with antibodies against programmed cell death-1 (PD-1). Proc Natl Acad Sci USA 110:15001-15006

23. Gardiner D, Lalezari J, Lawitz E, DiMicco M, Ghalib R, Reddy KR, Chang KM, Sulkowski M, Marro SO, Anderson J, He B, Kansra V, McPhee F, Wind-Rotolo M, Grasela D, Selby M, Korman AJ, Lowy I (2013) A randomized, double-blind, placebocontrolled assessment of BMS-936558, a fully human monoclonal antibody to programmed death-1 (PD-1), in patients with chronic hepatitis $\mathrm{C}$ virus infection. PLoS One 8:e63818

24. Topalian SL, Hodi FS, Brahmer JR, Gettinger SN, Smith DC, McDermott DF, Powderly JD, Carvajal RD, Sosman JA, Atkins MB, Leming PD, Spigel DR, Antonia SJ, Horn L, Drake CG, Pardoll DM, Chen L, Sharfman WH, Anders RA, Taube JM, McMiller TL, Xu H, Korman AJ, Jure-Kunkel M, Agrawal S, McDonald D, Kollia GD, Gupta A, Wigginton JM, Sznol M (2012) Safety, activity, and immune correlates of anti-PD-1 antibody in cancer. N Engl J Med 366:2443-2454

25. Liu J, Zhang E, Ma Z, Wu W, Kosinska A, Zhang X, Moller I, Seiz P, Glebe D, Wang B, Yang D, Lu M, Roggendorf M (2014) Enhancing virus-specific immunity in vivo by combining therapeutic vaccination and PD-L1 blockade in chronic hepadnaviral infection. PLoS Pathog 10:e1003856

26. Yalcin K, Danis R, Degertekin H, Alp MN, Tekes S, Budak T (2003) The lack of effect of therapeutic vaccination with a pre$\mathrm{S} 2 / \mathrm{S} \mathrm{HBV}$ vaccine in the immune tolerant phase of chronic HBV infection. J Clin Gastroenterol 37:330-335

27. Yalcin K, Acar M, Degertekin H (2003) Specific hepatitis B vaccine therapy in inactive HBsAg carriers: a randomized controlled trial. Infection 31:221-225

28. Pol S, Nalpas B, Driss F, Michel ML, Tiollais P, Denis J, Brecho C (2001) Efficacy and limitations of a specific immunotherapy in chronic hepatitis B. J Hepatol 34:917-921

29. Depla E, Van der Aa A, Livingston BD, Crimi C, Allosery K, De Brabandere V, Krakover J, Murthy S, Huang M, Power S, Babe L, Dahlberg C, McKinney D, Sette A, Southwood S, Philip R, Newman MJ, Meheus L (2008) Rational design of a multiepitope vaccine encoding T-lymphocyte epitopes for treatment of chronic hepatitis B virus infections. J Virol 82:435-450

30. Mancini-Bourgine M, Fontaine H, Brechot C, Pol S, Michel ML (2006) Immunogenicity of a hepatitis B DNA vaccine administered to chronic HBV carriers. Vaccine 24:4482-4489

31. Mancini-Bourgine M, Fontaine H, Scott-Algara D, Pol S, Brechot C, Michel ML (2004) Induction or expansion of T-cell responses by a hepatitis B DNA vaccine administered to chronic HBV carriers. Hepatology 40:874-882

32. Yang SH, Lee CG, Park SH, Im SJ, Kim YM, Son JM, Wang JS, Yoon SK, Song MK, Ambrozaitis A, Kharchenko N, Yun YD, Kim CM, Kim CY, Lee SH, Kim BM, Kim WB, Sung YC (2006) Correlation of antiviral T-cell responses with suppression of viral rebound in chronic hepatitis B carriers: a proof-of-concept study. Gene Ther 13:1110-1117

33. Yang FQ, Yu YY, Wang GQ, Chen J, Li JH, Li YQ, Rao GR, Mo GY, Luo XR, Chen GM (2012) A pilot randomized controlled trial of dual-plasmid HBV DNA vaccine mediated by in vivo electroporation in chronic hepatitis B patients under lamivudine chemotherapy. J Viral Hepat 19:581-593

34. Pancholi P, Lee DH, Liu Q, Tackney C, Taylor P, Perkus M, Andrus L, Brotman B, Prince AM (2001) DNA prime/canarypox boost-based immunotherapy of chronic hepatitis B virus infection in a chimpanzee. Hepatology 33:448-454

35. Cavenaugh JS, Awi D, Mendy M, Hill AV, Whittle H, McConkey SJ (2011) Partially randomized, non-blinded trial of DNA and MVA therapeutic vaccines based on hepatitis B virus surface protein for chronic HBV infection. PLoS One 6:e14626

36. Kosinska AD, Zhang E, Johrden L, Liu J, Seiz PL, Zhang X, Ma Z, Kemper T, Fiedler M, Glebe D, Wildner O, Dittmer U, Lu M, Roggendorf M (2013) Combination of DNA prime-adenovirus boost immunization with entecavir elicits sustained control of chronic hepatitis B in the woodchuck model. PLoS Pathog 9:e1003391

37. Martin J, Bosch O, Moraleda G, Bartolome J, Quiroga JA, Carreno V (1993) Pilot study of recombinant human granulocytemacrophage colony-stimulating factor in the treatment of chronic hepatitis B. Hepatology 18:775-780

38. Guptan RC, Thakur V, Kazim SN, Sarin SK (2002) Efficacy of granulocyte-macrophage colony-stimulating factor or lamivudine combination with recombinant interferon in non-responders to interferon in hepatitis B virus-related chronic liver disease patients. J Gastroenterol Hepatol 17:765-771

39. Xu DZ, Wang XY, Shen XL, Gong GZ, Ren H, Guo LM, Sun AM, Xu M, Li LJ, Guo XH, Zhen Z, Wang HF, Gong HY, Xu C, Jiang N, Pan C, Gong ZJ, Zhang JM, Shang J, Xu J, Xie Q, Wu TF, Huang WX, Li YG, Yuan ZH, Wang B, Zhao K, Wen YM (2013) Results of a phase III clinical trial with an HBsAg-HBIG immunogenic complex therapeutic vaccine for chronic hepatitis B patients: experiences and findings. J Hepatol 59:450-456

40. Xu DZ, Zhao K, Guo LM, Li LJ, Xie Q, Ren H, Zhang JM, Xu M, Wang HF, Huang WX, Bai XF, Niu JQ, Liu P, Chen XY, Shen XL, Yuan ZH, Wang XY, Wen YM (2008) A randomized controlled phase IIb trial of antigen-antibody immunogenic complex therapeutic vaccine in chronic hepatitis B patients. PLoS One 3:e2565

41. Das A, Ellis G, Pallant C, Lopes AR, Khanna P, Peppa D, Chen A, Blair P, Dusheiko G, Gill U, Kennedy PT, Brunetto M, Lampertico P, Mauri C, Maini MK (2012) IL-10-producing regulatory B cells in the pathogenesis of chronic hepatitis B virus infection. $\mathbf{J}$ Immunol 189:3925-3935

42. Dunn C, Peppa D, Khanna P, Nebbia G, Jones M, Brendish N, Lascar RM, Brown D, Gilson RJ, Tedder RJ, Dusheiko GM, Jacobs M, Klenerman P, Maini MK (2009) Temporal analysis of early immune responses in patients with acute hepatitis B virus infection. Gastroenterology 137:1289-1300 
43. Couper KN, Blount DG, Riley EM (2008) IL-10: the master regulator of immunity to infection. J Immunol 180:5771-5777

44. Brooks DG, Lee AM, Elsaesser H, McGavern DB, Oldstone MB (2008) IL-10 blockade facilitates DNA vaccine-induced T cell responses and enhances clearance of persistent virus infection. $\mathbf{J}$ Exp Med 205:533-541

45. Schurich A, Pallett LJ, Lubowiecki M, Singh HD, Gill US, Kennedy PT, Nastouli E, Tanwar S, Rosenberg W, Maini MK (2013) The third signal cytokine IL-12 rescues the anti-viral function of exhausted HBV-specific CD8 T cells. PLoS Pathog 9:e1003208

46. Del Vecchio M, Bajetta E, Canova S, Lotze MT, Wesa A, Parmiani G, Anichini A (2007) Interleukin-12: biological properties and clinical application. Clin Cancer Res 13:4677-4685

47. Buchbinder SP, Mehrotra DV, Duerr A, Fitzgerald DW, Mogg R, Li D, Gilbert PB, Lama JR, Marmor M, Del Rio C, McElrath MJ, Casimiro DR, Gottesdiener KM, Chodakewitz JA, Corey L, Robertson MN (2008) Efficacy assessment of a cell-mediated immunity HIV-1 vaccine (the Step Study): a double-blind, randomised, placebo-controlled, test-of-concept trial. Lancet 372:1881-1893

48. Colloca S, Barnes E, Folgori A, Ammendola V, Capone S, Cirillo A, Siani L, Naddeo M, Grazioli F, Esposito ML, Ambrosio M, Sparacino A, Bartiromo M, Meola A, Smith K, Kurioka A, O'Hara GA, Ewer KJ, Anagnostou N, Bliss C, Hill AV, Traboni C, Klenerman P, Cortese R, Nicosia A (2012) Vaccine vectors derived from a large collection of simian adenoviruses induce potent cellular immunity across multiple species. Sci Transl Med 4:115ra112

49. Barnes E, Folgori A, Capone S, Swadling L, Aston S, Kurioka A, Meyer J, Huddart R, Smith K, Townsend R, Brown A, Antrobus R, Ammendola V, Naddeo M, O'Hara G, Willberg C, Harrison A, Grazioli F, Esposito ML, Siani L, Traboni C, Oo Y, Adams D, Hill A, Colloca S, Nicosia A, Cortese R, Klenerman P (2012) Novel adenovirus-based vaccines induce broad and sustained $\mathrm{T}$ cell responses to HCV in man. Sci Transl Med 4:115ra111

50. Webster GJ, Reignat S, Brown D, Ogg GS, Jones L, Seneviratne SL, Williams R, Dusheiko G, Bertoletti A (2004) Longitudinal analysis of CD8 $+\mathrm{T}$ cells specific for structural and nonstructural hepatitis B virus proteins in patients with chronic hepatitis B: implications for immunotherapy. J Virol 78:5707-5719

51. Kamatani Y, Wattanapokayakit S, Ochi H, Kawaguchi T, Takahashi A, Hosono N, Kubo M, Tsunoda T, Kamatani N, Kumada H, Puseenam A, Sura T, Daigo Y, Chayama K, Chantratita W, Nakamura Y, Matsuda K (2009) A genome-wide association study identifies variants in the HLA-DP locus associated with chronic hepatitis B in Asians. Nat Genet 41:591-595

52. Kelly C, Folgori A, Capone S, Stafford E (2011) A therapeutic vaccine for $\mathrm{HCV}$ based on novel, rare, adenoviral vectors. $\mathrm{J}$ Hepatol 54:S29
53. Kelly C, Folgori A, Capone S (2012) In vivo antigenic targets of $\mathrm{T}$ cells induced by adenoviral vectored vaccines in patients with chronic HCV infection. J Hepatol S468

54. Barnes E, Gelderblom HC, Humphreys I, Semmo N, Reesink HW, Beld MG, van Lier RA, Klenerman P (2009) Cellular immune responses during high-dose interferon- $\alpha$ induction therapy for hepatitis C virus infection. J Infect Dis 199:819-828

55. Liang Y, Shilagard T, Xiao SY, Snyder N, Lau D, Cicalese L, Weiss H, Vargas G, Lemon SM (2009) Visualizing hepatitis C virus infections in human liver by two-photon microscopy. Gastroenterology 137:1448-1458

56. Habersetzer F, Honnet G, Bain C, Maynard-Muet M, Leroy V, Zarski JP, Feray C, Baumert TF, Bronowicki JP, Doffoel M, Trepo C, Agathon D, Toh ML, Baudin M, Bonnefoy JY, Limacher JM, Inchauspe $G$ (2011) A poxvirus vaccine is safe, induces T-cell responses, and decreases viral load in patients with chronic hepatitis C. Gastroenterology 141(890-899):e891-e894

57. Di Bisceglie AM, Janczweska-Kazek E, Habersetzer F, Mazur W, Stanciu C, Carreno V, Tanasescu C, Flisiak R, Romero-Gomez M, Fich A, Bataille V, Toh ML, Hennequi M, Zerr P, Honnet G, Inchauspe G, Agathon D, Limacher JM, Wedemeyer H (2014) Efficacy of immunotherapy with TG4040, peg-interferon, and ribavirin in a phase 2 study of patients with chronic $\mathrm{HCV}$ infection. Gastroenterology 147(119-131):e113

58. Lucifora J, Xia Y, Reisinger F, Zhang K, Stadler D, Cheng X, Sprinzl MF, Koppensteiner H, Makowska Z, Volz T, Remouchamps C, Chou WM, Thasler WE, Huser N, Durantel D, Liang TJ, Munk C, Heim MH, Browning JL, Dejardin E, Dandri M, Schindler M, Heikenwalder M, Protzer U (2014) Specific and nonhepatotoxic degradation of nuclear hepatitis B virus cccDNA. Science 343:1221-1228

59. Lanford RE, Guerra B, Chavez D, Giavedoni L, Hodara VL, Brasky KM, Fosdick A, Frey CR, Zheng J, Wolfgang G, Halcomb RL, Tumas DB (2013) GS-9620, an oral agonist of Toll-like receptor-7, induces prolonged suppression of hepatitis $\mathrm{B}$ virus in chronically infected chimpanzees. Gastroenterology 144 15081517,1517 e1501-1510

60. Purcell DF, Elliott JH, Ross AL, Frater J (2013) Towards an HIV cure: science and debate from the International AIDS Society 2013 symposium. Retrovirology 10:134

61. Zhong G, Yan H, Wang H, He W, Jing Z, Qi Y, Fu L, Gao Z, Huang Y, Xu G, Feng X, Sui J, Li W (2013) Sodium taurocholate cotransporting polypeptide mediates woolly monkey hepatitis B virus infection of Tupaia hepatocytes. J Virol 87:7176-7184

62. Yan H, Zhong G, Xu G, He W, Jing Z, Gao Z, Huang Y, Qi Y, Peng B, Wang H, Fu L, Song M, Chen P, Gao W, Ren B, Sun Y, Cai T, Feng X, Sui J, Li W (2012) Sodium taurocholate cotransporting polypeptide is a functional receptor for human hepatitis B and D virus. Elife 1:e00049 